
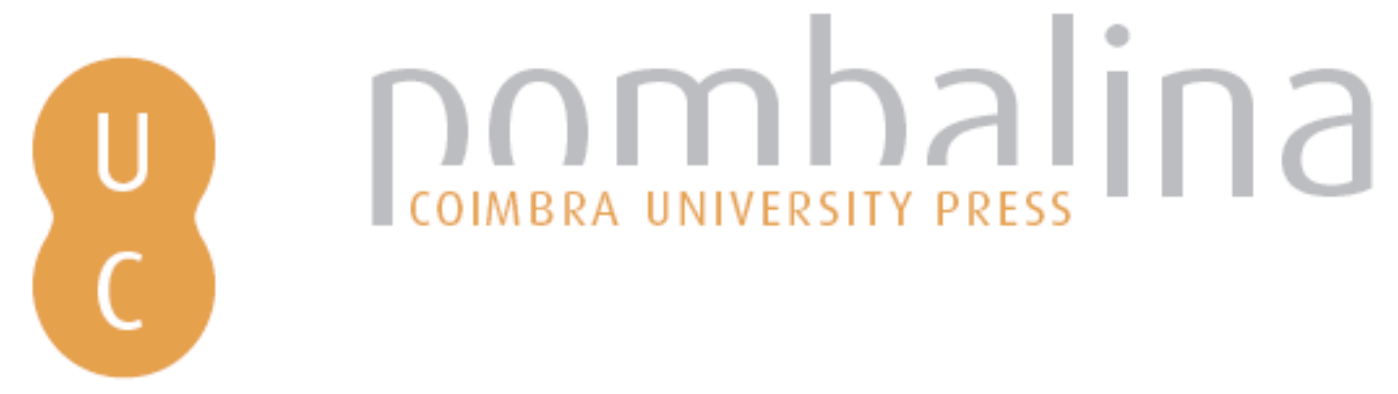

The flammability of ornamental species with potential for use in highways and wildland urban interface (WUI) in southern Brazil

Autor(es): $\quad$ Biondi, Daniela; Batista, Antonio Carlos; Martini, Angeline

Publicado por: Imprensa da Universidade de Coimbra

URL

persistente: URI:http://hdl.handle.net/10316.2/34287

DOI: DOI:http://dx.doi.org/10.14195/978-989-26-0884-6_108

Accessed : $\quad$ 26-Apr-2023 14:17:29

A navegação consulta e descarregamento dos títulos inseridos nas Bibliotecas Digitais UC Digitalis, UC Pombalina e UC Impactum, pressupõem a aceitação plena e sem reservas dos Termos e Condições de Uso destas Bibliotecas Digitais, disponíveis em https://digitalis.uc.pt/pt-pt/termos.

Conforme exposto nos referidos Termos e Condições de Uso, o descarregamento de títulos de acesso restrito requer uma licença válida de autorização devendo o utilizador aceder ao(s) documento(s) a partir de um endereço de IP da instituição detentora da supramencionada licença.

Ao utilizador é apenas permitido o descarregamento para uso pessoal, pelo que o emprego do(s) título(s) descarregado(s) para outro fim, designadamente comercial, carece de autorização do respetivo autor ou editor da obra.

Na medida em que todas as obras da UC Digitalis se encontram protegidas pelo Código do Direito de Autor e Direitos Conexos e demais legislação aplicável, toda a cópia, parcial ou total, deste documento, nos casos em que é legalmente admitida, deverá conter ou fazer-se acompanhar por este aviso.

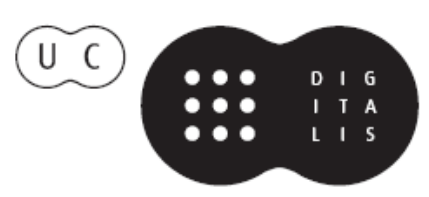




\section{ADVANCES IN}

Forest Fire

\section{RESEARCH}

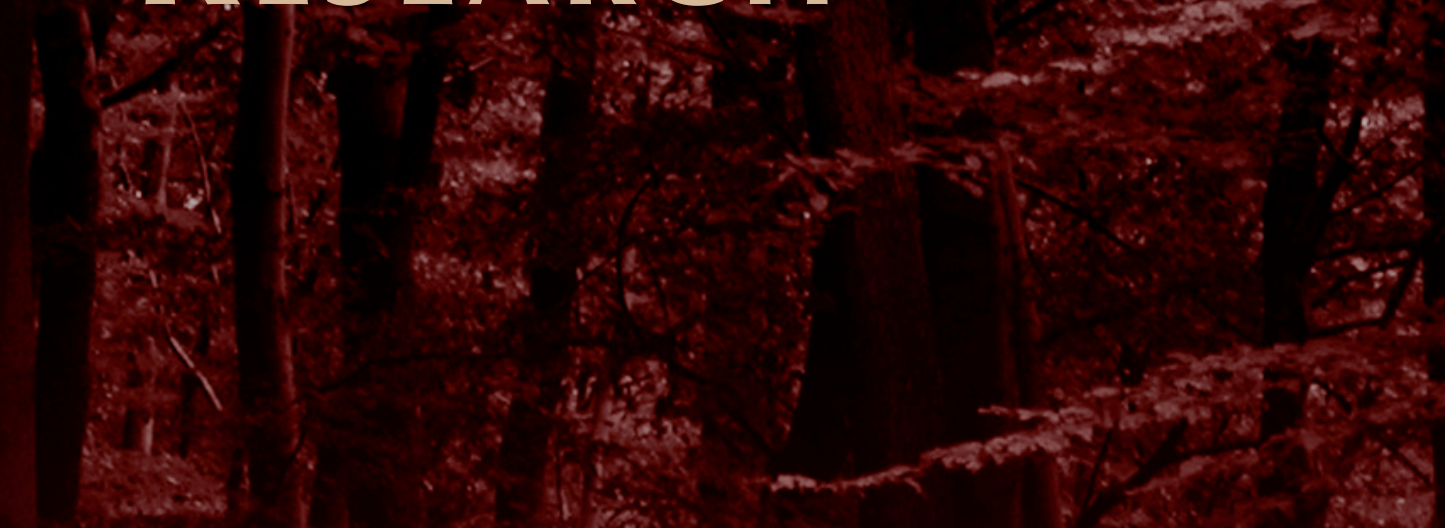

\section{DOMINGOS XAVIER VIEGAS}

\section{EDITOR}




\title{
The flammability of ornamental species with potential for use in highways and wildland urban interface (WUI) in southern Brazil
}

\author{
Daniela Biondi, Antonio Carlos Batista, Angeline Martini \\ ${ }^{a}$ Universidade Federal do Paraná, Av. Lothário Meisnner, 900 Curitiba-Brasil, dbiondi@ufpr.br, \\ batistaufpr@ufpr.br, martini.angeline@gmail.com
}

\begin{abstract}
The areas of wildland urban interface (WUI) are sites that have mixed characteristics, from the influence of rural and urban areas. With the increase in urban population in national and global level, the areas are losing this characteristic transition with diversity of functions. One of the most common problems due to this rural/urban proximity are forest fires that cause damage to many homes in urban areas. The highway is a transportation infrastructure located in the area of the wildland urban interface that can serve as a barrier or mitigation of forest fires that threaten urban areas, through its landscaping. For the highway integrate with the local landscape is necessary that this landscaping provide conservation or ecological, cultural and aesthetic function. The objective of this study was to evaluate the flammability of native ornamental species with potential for use in the prevention of forest fires in the vicinity of highways. The selected species are native from southern Brazil due the presence of interesting aesthetic features. They are: Aspilia montevidensis (Spreng.) Kuntze - the family Asteraceae species with ornamental potential both by the beauty of the flowers of bright yellow color, like the long flowering period that occurs almost all year round and can be used in landscaping as ground cover, is indicated for public areas by not requiring maintenance and also for treatment of degraded areas; Peltodon rugosus Tolm. - herbaceous species of the family Lamiaceae, native to southern Brazil, on "Estepe Gramíneolenhosa" presents both its ornamental inflorescence globose form and by its leaves with visible vein, can be used in degraded areas due to its hardiness; and Verbena rigida Spreng - the Verbenaceae family, is a little branched herbaceous perennial, rhizomatous, erect, popularly known as "grass-wire", native of the fields of the plateau in southern Brazil, can reach 20-30 cm in height with decorative flowering, stiff and rough leaves, inflorescences with small flowers blue-purple color formed in spring-summer. For each species were performed 50 burnings in epiradiator of $1 \mathrm{~g}$ of material freshly harvested. During the experiments burning in the epiradiator, the following variables were collected: Frequency of ignition (FI), time to ignition (TI), duration of combustion (DC), flame height (AC) and combustion index (IC). Statistical analysis was done by SNK test at $95 \%$ probability. The results of the species flammability show that Aspilia montevidensis and Peltodon rugosus differ statistically of the Verbena rigida for FI and TI, indicating to be less flammable, although all species show low flammability. Given the results, it is concluded that the analyzed species exhibit excellent characteristics for landscape composition on highways both due its aesthetic appearance and functional, and can also serve as a barrier against forest fires in areas of wildland urban interface in southern Brazil.
\end{abstract}

Keywords: in forest fuels, epiradiator, native ornamental species.

\section{Introduction}

The Wildland Urban Interface areas, otherwise known as WUI, are places that have mixed features, with influence of rural and urban areas (BIONDI, 2013). Are multifunctional spaces where there are fragmented presence of land use and the absence of urban structure, with deep economic, social and physical transformations and that still feature a dynamic closely linked to the presence of a nucleus around (MIRANDA, 2009).

Radeloff et al. (2005) complements the concept of WUI stating that this area is a zone of conflict between humans and the environment, where there is destruction of houses by forest fires, fragmentation of natural habitats, introduction of exotic species and the loss of biodiversity.

According to Biondi (2013), with the increase of urban population, these areas are losing that characteristic of transition and acquiring a rural or urban physiognomy, moreover, to be removed shall 
become the boundary between urban and rural zone. With that, one of the most common problems that occur are the forest fires that eventually reach the homes of the urban areas. Thus, since the highway is a transportation infrastructure in urban and rural transition area, could serve as a barrier and mitigation or forest fires that threaten urban areas

The assessment of forest fires risk on the landscape planning of roads should be an essential element to reduce the damage caused by the fire in the wildland urban interface areas of Paraná-Brazil (BIONDI et al., 2013). According to the same authors, from the characterization of the degree of risk of fire it is possible to perform the selection and planning of less flammable species composition in order to impede the spread of fire.

The knowledge of how the species differ in their flammability characteristics it is necessary to develop more reliable lists of plants recommended for residential landscaping in wildland - urban interface (WHITE and ZIPPERER, 2010).

According Ganteaume et al. (2013) currently, there is no research on the evaluation of flammability of ornamental species.

Flammability can be defined as how easy it is for a material to catch fire, both spontaneously and through exposure to certain conditions (ZHANG et al., 2011). According to Anderson (1970) flammability initially was defined based on three components: the potential of ignition, which is the time needed for the fuel reaches the ignition after being exposed to a source of heat; sustainability, refers to the ability to maintain combustion after ignition; and combustibility, which is the rate of burn after ignition.

The plant species that provide the fuel for the fires have specific flammabilities (CURT et al, 2011), which varies according to the species and with moisture content (VÉLEZ, 2000). In addition, the volatile organic compounds, such as monoterpenes, constitute other possible factors contributing to the increased flammability vegetation (ALESSIO et al., 2008).

The aim of this study was to evaluate the flammability of native ornamental species with potential for use in the prevention of forest fires in the surrounding highways.

\section{Methods}

The experiment was conducted in the laboratory of forest fires at the Campus III of the "Universidade Federal Paraná" (UFPR), in Curitiba, Brazil. The original vegetation of the city, before the anthropic action, consisted of "Estepe Gramíneo-Lenhosa" (fields), intermingled of arboreal groupings (with the presence of Araucaria angustifolia), next the downloaded and streams (RODERJAN et al., 2002)

The climate of Curitiba, according to Köppen classification, is $\mathrm{Cfb}$, humid subtropical, humid, without dry season, with cool summers and winters with frequent frosts and occasional snow precipitation. Has average temperatures of $19.7^{\circ} \mathrm{C}$ in summer and $13.4^{\circ} \mathrm{C}$ in winter, with average annual precipitation of $1419.9 \mathrm{~mm}$ (IPPUC, 2011).

The species selected for the experiment are native from southern Brazil, on the "Estepe GramíneoLenhosa", and present interesting aesthetic characteristics for use in landscaping. They are: Aspilia montevidensis (Spreng.) Kuntze, Peltodon rugosus Tolm and Verbena rígida Spreng.

Aspilia montevidensis is a species of the Asteraceae family that boasts great potential both for ornamental beauty of flowers of bright yellow color, as for the long flowering period that occurs almost the whole year. In landscaping, can be used as lining plant in flower beds to homogeneous full sun, being indicated for public areas and also in degraded areas, not requiring great care in maintenance. 


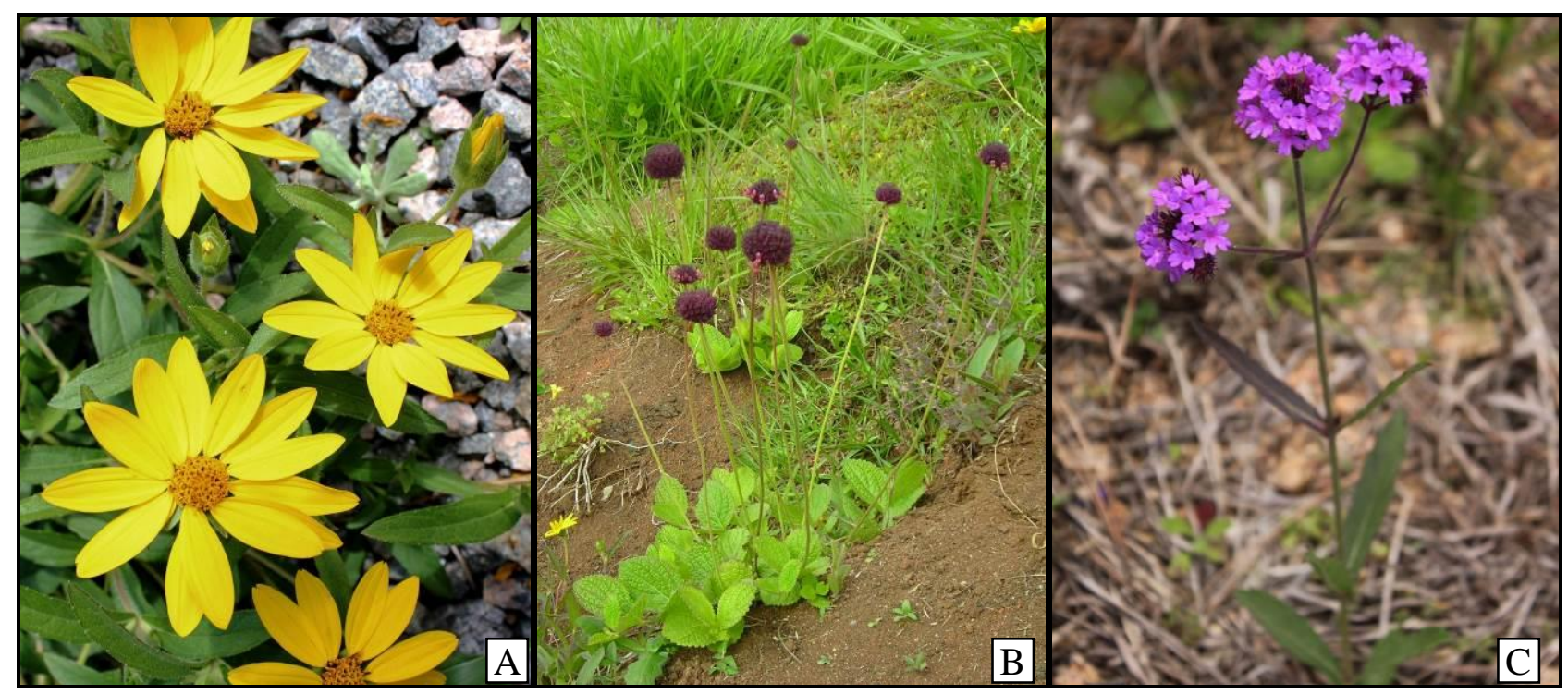

Figure 1. The selected species: A) Aspilia montevidensis; B) Peltodon rugosus, C) Verbena rigida

Peltodon rugosus, of the family Lamiaceae, is a herbaceous plant which features ornamental potential both for its inflorescence shape globe, as by their apparent ribbed leaves. Due to its hardiness can be used in recovery of degraded areas.

Verbena rigida, family Verbenaceae, is a little branched herbaceous perennial, rhizomatous, erect, popularly known as wire weed. Can reach of 20 to $30 \mathrm{~cm}$ tall, with decorative flourish, stiff and rough leaves, inflorescences with small flowers-blue color formed in spring-summer.

The concept of flammability can be reduced to distinct aspects of combustion, according to the type of metric used in its assessment (WHITE and ZIPPERER, 2010). Thus, it can be experimentally evaluated by fuel burning in the laboratory, whether in the form of discrete elements (such as a leaf or branch), or as a fuel bed and a heterogeneous set of individual units (FERNANDES and CRUZ, 2012). In this research the flammability was analyzed from the combustion experiments, performed in a chapel (a draught-free location), with an epiradiator of $500 \mathrm{~W}$ nominal power constant, kept in a controlled temperature range of $250{ }^{\circ} \mathrm{C}$. The material used in the experiment consists only of leaves of selected species, which were collected in the vicinity of the building of Forestry and Wood of the UFPR, moments before the beginning of the experiment, which was carried out within a maximum of 2 hours after collecting.

Flammability tests were conducted according to the methodology proposed by Petriccione et al. (2006) and Petriccione (2006). For each species were performed 50 repetitions, each with $1 \mathrm{~g}$ of green fuel material, determined with the aid of a precision balance. The forests fuel was exposed to epiradiator for 60 seconds. In all the steps performed were taken the care required to be no direct contact with the material, so as to avoid interference in their properties.

During the experiment, conducted in the epiradiator, were collected the following variables: ignition frequency (FI), ignition time (TI), duration of combustion (DC) and height of the flame (AC). Flammability values were obtained from the potential of ignition (PI) and the average combustion time (TC) based on table 1 (VALETTE, 1990). This index is calculated based on the values of frequency ignition (FI), which refers to the number of positive ignitions (less than 60 seconds) of a total of 50 repetitions and the combustion time (time that the flame remains visible). Statistical analysis of the data was made by SNK test the $95 \%$ probability. 
Table 1. Flammability Values (Valette, 1990)

\begin{tabular}{ccccccc}
\hline $\begin{array}{c}\text { PI } \\
\text { TC - s }\end{array}$ & $<25$ & $25-38$ & $39-48$ & $42-44$ & $45-47$ & $\mathbf{4 8 - 5 0}$ \\
\hline$>32,5$ & 0 & 0 & 0 & 1 & 1 & 2 \\
\hline $27,5-32,5$ & 0 & 0 & 1 & 1 & 2 & 2 \\
\hline $22,5-27,5$ & 0 & 0 & 1 & 2 & 2 & 2 \\
\hline $17,5-22,5$ & 1 & 1 & 2 & 2 & 3 & 3 \\
\hline $12,5-17,5$ & 1 & 1 & 2 & 3 & 3 & 4 \\
\hline$<12,5$ & 1 & 2 & 3 & 3 & 4 & 5 \\
\hline
\end{tabular}

Note:

PI - potential of ignition (positive number of ignitions a total of 50 trials); TC - combustion time in seconds.

$0=$ very low flammability; $1=$ low flammability; 2 = flammable; $3=$ moderately flammable; $4=$ very flammable;

$5=$ extremely flammable.

\section{Results}

The variables of flammability were analyzed separately, which has shown the difference in behavior between the species studied. The ignition timing in each repetition performed for the species can be observed in Figure 2.
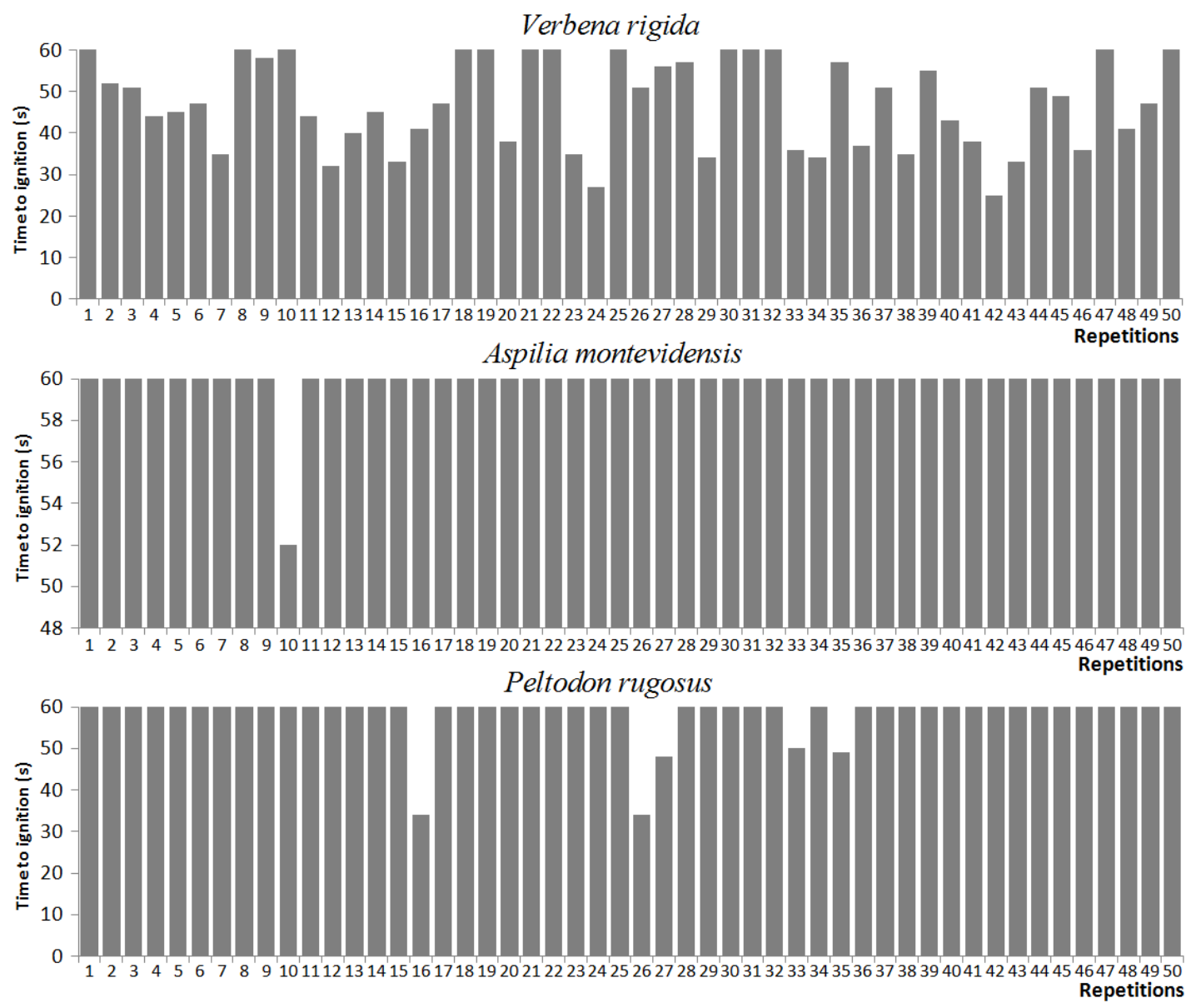

Figure 2. TI of the species in each repetition

It is observed that Verbena rigida was the species that presented greater variation in TI, being that most of the repetitions performed less than $60 \mathrm{~s}$, corresponding to positive ignitions. 
Aspilia montevidensis presented only one positive ignition, while Peltodon rugosus presented five positive ignitions. These results support the use of Aspilia montevidensis and Peltodon rugosus as barriers to the ignition of the forest fires in the edges of the WUI.

DC and AC variables were only possible to analyze in detail the species Verbena rigida (Figure 3 and 4). This is because the other species present in the vast majority of the repetitions, TI greater than 60 seconds, indicating negative ignition, and if "no ignition, no combustion".

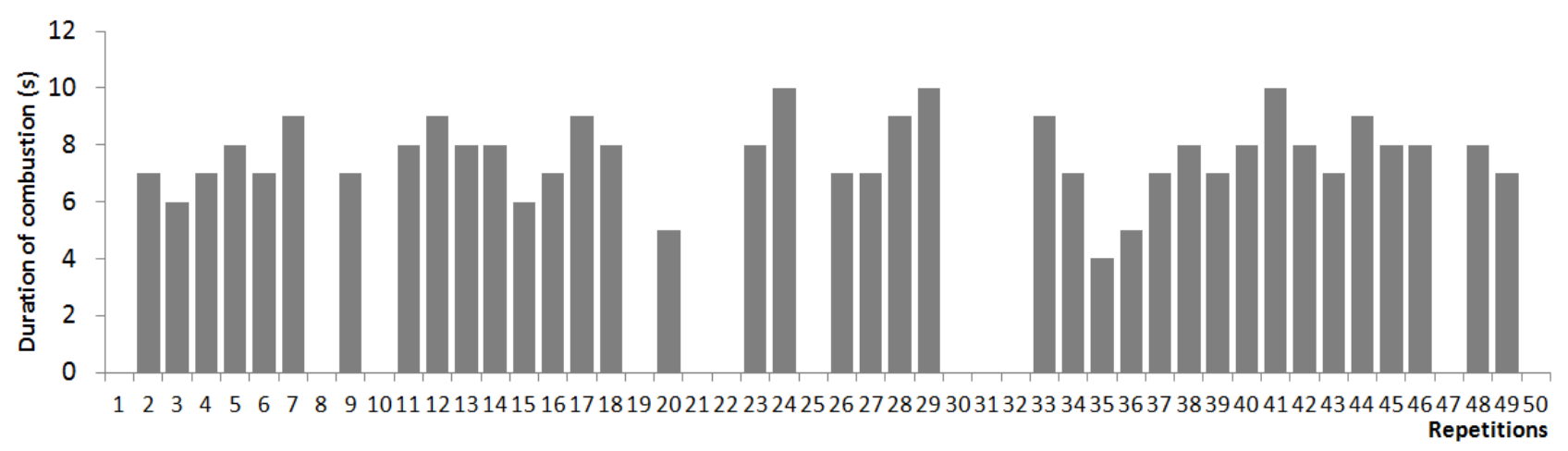

Figure 3. DC of Verbena rigida in each repetition.

It can be observed that there was wide variation in the DC of species in the repetitions performed. The average DC of Verbena rigida lasted 7.6 seconds, varying between 4 and 10 seconds.

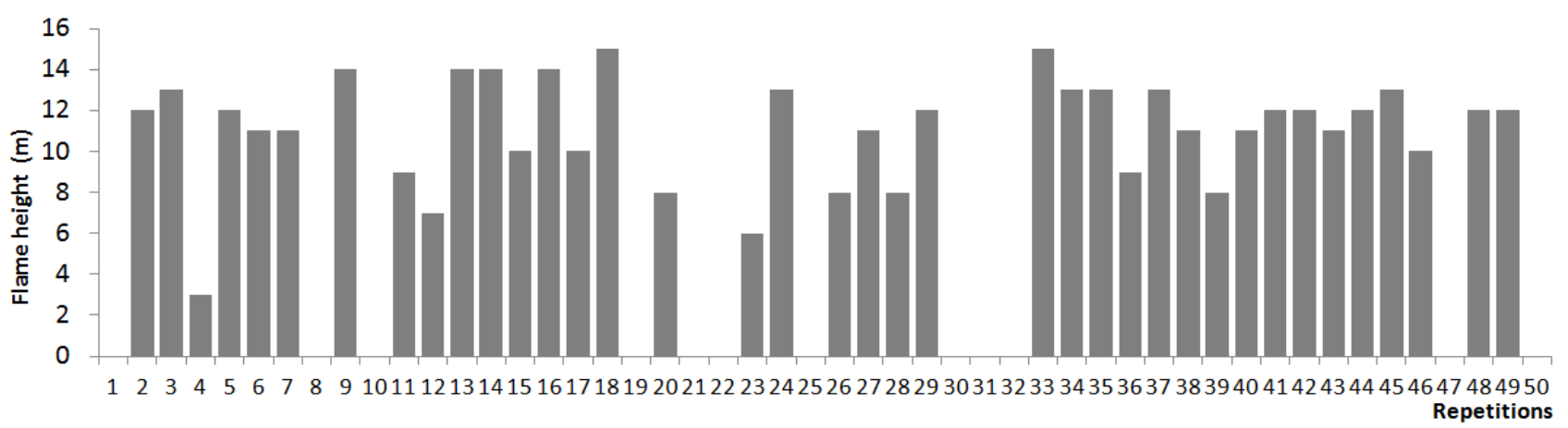

Figure 4. AC of Verbena rigida in each repetition

The flame height of Verbena rigida also showed wide variation, with an average of $11.1 \mathrm{~cm}$, ranging from 3.0 to $15.0 \mathrm{~cm}$.

After the analysis of the variables held separately, was assessed the flammability of the species, which allows to obtain a more accurate result regarding its use as a fuelbreak (table 1).

Table 1. Avaliação da inflamabilidade de espécies ornamentais

\begin{tabular}{lccccl}
\hline Species & FI (\%) & TI (s) & DC (s) & AC (cm) & Combustion Index (IC) \\
\hline Aspilia montevidensis & $2($ a) & $>60($ a) & 13 & 9 & 1 - Low flammability \\
Peltodon rugosus & $10($ a) & $>60($ a) & 9,2 & 14 & 1 - Low flammability \\
Verbena rigida & $76($ b) & $43,9($ b) & 7,6 & 11,1 & 2 - Moderately flammable \\
\hline
\end{tabular}

Note:

FI -ignition frequency; TI - ignition time; DC duration of combustion; AC - height of the flame.

For FI and TI variables, means followed by the same letter in the column do not differ at 5\% significance level by SNK test.

It is observed that Aspilia montevidensis and Peltodon rugosus differ statistically from Verbena rigida for variables FI and TI, indicating they are of low flammability although all species demonstrate weak flammability. 


\section{Conclusion}

By the results, it is concluded that the analyzed species exhibit excellent characteristic to landscape composition on highways both for its aesthetic aspect as functional, and may also serve as a barrier against forest fires in WUI areas in southern Brazil.

In relative terms of flammability can be concluded that the species analyzed presented the following behavior: Aspilia montevidensis < Peltodon rugosus < Verbena rígida.

\section{References}

Alessio GA, Peñuelas J, Llusià J, Ogaya R, Estiarte M, De Lillis M (2008) Influence of water and terpenes on flammability in some dominant Mediterranean species. International Journal of Wildland Fire 17, 274-286.

Anderson HE (1970) Forest fuel ignitibility. Fire Technology 6, 312-319.

Biondi D (2013) 'Paisagismo Rodoviário: indicação de espécies.' (O Autor: Curitiba)

Biondi D, Batista AC, Martini A (2013) Fire risk in the road landscape patterns of the state of Paraná, Brazil - planning grants for the Wildland-Urban Interface. Pacific Southwest Research Station General technical report PSW-GTR-245, $326-337$.

Curt T, Schaffhauser A, Borgniet L, Dumas C, Estève R, Ganteaume A, Jappiot M, Martin W, N'Diaye A, Poilvet B (2011) Litter flammability in oak woodlands and shrublands of southeastern France. Forest Ecology and Management 261, 2214-2222.

Fernandes PM, Cruz MG (2012) Plant flammability experiments offer limited insight into vegetationfire dynamics interactions. New Phytologist 194, 606-609.

Ganteaume A; Jappiot M; Lampion C; Guijarro M; Hernando C (2013) Flammability of Some Ornamental Species in Wildland-Urban Interfaces in Southeastern France: Laboratory Assessment at Particle Level. Environmental Management 52,467-480.

Instituto de Pesquisa e Planejamento Urbano de Curitiba - IPPUC (2011) 'Desenvolvimento sustentável: Indicadores de sustentabilidade de Curitiba - 2010.' (IPPUC: Curitiba)

Miranda LIB (2009) Planejamento em áreas de transição rural-urbana: velhas novidades em novos territótios. Revista Brasileira de Estudos Urbanos e Regionais 11, 25-40.

Petriccione M (2006) Infiammabilità della lettiera diverse specie vegetali di ambiente Mediterraneo. Tesi di Dottorato in Biologia Applicata - Università Degli Studi di Napoli Federico II.

Petriccione M, Moro C, Rutigliano FA (2006) Preliminary studies on litter flammability in Mediterranean Region. In: International Conference on Forest Fire Research 5, Proceedings of... Portugal.

Radeloff VC, Hammer RC, Stewart I, Fried JS, Holcomb SS, Mckeefry JF (2005) The wildland -urban interface in the United States. Ecological Applications 15, 799-805.

Roderjan CV, Galvão F, Kuniyoshi YS, Hatschbach GG (2002) As unidades fitogeográficas do Estado do Paraná. Ciência \& Ambiente 24, 75-92.

Valette, JC (1990) Inflammabilités des espèces forestières méditerranéennes. Rev. Forest. Fr 42, 7692.

Vélez R (2000) 'La defensa contra Incendios Forestales: Fundamentos y experiencias.' (McGraw Hill: Madrid)

White RH, Zipperer WC (2010) Testing and classification of individual plants for fire behaviour: plant selection for the wildland-urban interface. International Journal of Wildland Fire 19, 213-227.

Zhang Z, Zhang H, Zhou D (2011) Flammability characterization of grassland species of Songhua Jiang-Nen Jian Plain (China) using thermal analysis. Fire Safety Journal 46, 283-288. 